11. A apreciação dubitativa do realismo começa nesse trecho citado, quando Descartes parafraseia o princípio realista, e se encerra com a descoberta das coisas simples e universais, a partir da qual tem início a apreciação dubitativa do idealismo, que decidimos não abordar aqui, esperando fazê-lo em outra oportunidade.

12. "Exceto, talvez, que eu me compare a esses dementes, cujo cérebro está de tal maneira perturbado pela e ofuscado pelos negros vapores da bile que amiúde garantem que são reis, enquanto são bastante pobres; que estão trajados de ouro e púrpura, enquanto estão totalmente nus; ou imaginam ser vasos ou possuir um corpo de vidro. São loucos e eu não seria menos excêntrico se me pautasse por seus exemplos" (Descartes 2, AT IX, 14).

13. Por exemplo, em alguns sonhos extravagantes, ocorre de a fisionomia de uma pessoa repentinamente assumir a de outra. Ora, como tal coisa é impossível na realidade, logo se percebe muito claramente que se trata de um sonho.

14. "Contudo, devo aqui ponderar que sou homem, e, consequentemente, que tenho o hábito de dormir e de representar, em meus sonhos, as mesmas coisas, ou algumas vezes menos prováveis, que esses dementes despertos. Quantas vezes me aconteceu sonhar, durante a noite, que me encontrava neste lugar, vestido e próximo do fogo, apesar de me achar totalmente nu em minha cama?" (Descartes 2, AT IX, 14-15).

15. Tomás de Aquino, aliás, já aludia, no século XIII, ao engano dos sentidos. Seguindo Agostinho, ele afirma que o problema dos sentidos é que só percebem o que é mutável e, como a verdade é imutável, não pode ser percebida por eles. Em razão do seu caráter mutável, não existe nenhuma coisa sensível que não encerre algo que se assemelha ao falso, de maneira que não é possível discernir. Diz ele: "Tudo quanto apreendemos através dos sentidos corporais, também quando as coisas não estão presentes aos sentidos, recebemos as imagens dessas coisas como se nos estivessem presentes, tal como acontece também no sono ou em acessos de furor. Ora, a verdade nada encerra em si que se assemelhe ao falso, logo não pode ser apreendida pelos sentidos" (Tomás de Aquino 12, q. I, a. 4). Portanto, Tomás e Descartes concordam que, na atividade onírica, experimentamos os objetos tão presentes, próximos e tão sensíveis que não é possível discernir se eles são ou não reais.

16. Para uma análise mais detalhada acerca do debate entre Martial Gueroult e Harry

G. Frankfurt em torno das coisas simples e universais, veja-se Forlin, 4, p. 57-81.

17. "Talvez seja por isso que nós não concluamos mal se afirmarmos que a física, a astronomia, a medicina e todas as outras ciências dependentes da consideração das coisas compostas são muito dúbias e incertas". (Descartes 2, AT IX, 16).

\section{A ÉTICA DOS ESTOICOS ANTIGOS E O ESTEREÓTIPO ESTOICO NA MODERNIDADE*}

Drayfine Teixeira Moura

Resumo: Tendo em vista que o estoicismo é a corrente helenística que mais influenciou a Filosofia ocidental, a intenção deste artigo é apresentar e esclarecer alguns dos mais comuns estereótipos que a modernidade cunhou acerca da teoria estoica. Para tanto, fazemos uma apresentação dos principais aspectos da ética estoica e analisamos alguns conceitos que, mais tarde, serão os principais alvos de crítica à escola do pórtico. Acusada de ser uma corrente filosófica que prega o comodismo, a aniquilação dos sentimentos e o domínio absoluto da razão sobre as paixões, o estoicismo é muitas vezes mal interpretado por seus opositores. Comentamos também neste texto a crítica feita por Spinoza no prefácio do quinto livro da Ética, cuja ênfase em conceitos como "experiência" e "vontade" ajuda a esclarecer como o estoicismo é encarado na modernidade.

Palavras-chave: Ética, Ética estoica, Estoicismo romano, Estoicismo na Filosofia moderna, Estoicos e Spinoza.

\section{A teoria ética dos primeiros estóicos}

O estoicismo é uma escola helenística fundada por Zenão de Cício ao final do séc. II a.C e cuja influência se estende desde a Grécia antiga até filosofias recentes do sec. XIX, como podemos encontrar nos estudos contemporâneos que sondam as influências estoicas em Kant e Freud. ${ }^{1}$

A escola estoica defendia uma doutrina una e coerente e muitas vezes representavam sua doutrina pela imagem de uma árvore (onde o caule seria a física, os galhos, a lógica; e as folhas seriam a ética, ou moral);

*Artigo produzido durante Iniciação Científica financiada pela bolsa PRP/Santader/FFLCH 
Laércio nos fala dessa divisão, ${ }^{2}$ e apontando para a discordância entre pensadores estoicos sobre a importância de cada uma das partes sobre as outras, torna ainda mais evidente que este era um recorte epistemológico e que, na prática, a teoria estava interligada.

"Não preferem nenhuma dessas partes à outra, segundo escrevem alguns deles, mas as misturam e as ensinam juntas. Outros põem em primeiro lugar a lógica, em segundo a física e em terceiro a ética. (...) Mas Diógenes Talemaico inicia com a ética; Apolodoro põe-na como segunda; e Panécio, com Posidônio, começa pela física" (LAÉRCIO, 1949, p. 31)

É previsível que, com a filosofia sistematicamente dividida, não tardou para alguns pensadores privilegiarem e desenvolverem áreas específicas de seu interesse enquanto deixavam de lado aspectos que julgavam suficientemente desenvolvidos ou menos importantes no cenário em que viviam. Sendo assim, veremos que no decorrer dos anos a ética estoica foi ganhando terreno e germinou com toda sua força no princípio da Roma Imperial, transformando os tratados e escritos morais no ponto central da doutrina estoica. ${ }^{3}$

Nesse texto, portanto, seguiremos o exemplo dos romanos e nos concentraremos na exposição dos conceitos éticos, pois nosso principal objetivo é determinar até que ponto o que chamamos na contemporaneidade e na modernidade de "ética estoica" tem a ver com os fundamentos da escola em sua origem. Longe de querermos traçar uma linha cronológica que investigue todas as alterações sofridas pela doutrina ao curso da história - o que aqui seria inviável - tentaremos somente caracterizar o modo como os estóicos clássicos entendiam sua ética, em oposição a como nós a vemos hoje - depois de tantos séculos de influências e modificações.
Temos com isso a sincera esperança de trazer à luz os equívocos causados por estereótipos comumente associados, na modernidade e nos dias de hoje, ao estoicismo. Se nossa esperança não se concretizar, contentarnos-emos com o estóico consolo do imperador Aurélio:

Ars vivendi luctatoriae similior, quam saltatoriae, quatenus adversus ea, quae incidunt et improvisa sunt, parata et immota consistit ${ }^{4}$.

Expor a ética estoica não é uma tarefa fácil; assim como o resto da doutrina, a ética possui uma estrutura fechada em si mesma, constituindo um sistema onde um conceito não pode existir independente dos demais e onde a omissão de algo pode prejudicar o entendimento do todo, como nos testemunha Cícero ao falar da ética através de Catão, em seu diálogo De Finibus: "Pode você imaginar qualquer outro sistema em que a remoção de uma única letra, como uma peça encaixada, provoque a ruína de todo o edifício?"(apud: SCHOFIELD 12, p. 262)

No entanto, selecionamos para esta exposição apenas os conceitos que nos pareceram relevantes para a compreensão do fundamento da ética estoica, assim como os conceitos que servirão de requisito para delinearmos, ao final deste texto, algumas diferenças existentes entre a doutrina estoica e certos estereótipos modernos e contemporâneos a seu respeito.

O principal conceito da ética estoica - assim como de muitas outras doutrinas - é a virtude; é através dela que o estoico persegue o ideal do Sábio e guia sua conduta ética e moral. Mas o que eles entendem por virtude? Para o estoicismo o fundamento da virtude consiste no movimento natural de todo animal em se auto $\operatorname{preservar}^{6}$ e viver segundo a natureza: "O fim é viver conforme à natureza, quer dizer, viver segundo a virtude, de vez que a natureza nos conduz a ela.'(LAERCIO 3, p.62) 
No entanto, a virtude é um estado propriamente humano e o homem não é um animal como outro qualquer: existe nele uma característica fundamental - que não deixa de ser natural - e que lhe dá a possibilidade de seguir a natureza mais perfeitamente do que qualquer outro ser. Esse privilégio se chama razão. ${ }^{7}$

A razão (logós) é um atributo natural do homem responsável por conduzi-lo a viver conforme a ordem natural do universo. ${ }^{8} \mathrm{Ou}$ seja, o homem age naturalmente quando segue a razão, e seguindo a razão se torna virtuoso; sendo virtuoso alcança a felicidade; como nos dizem os relatos de Laércio: "A virtude é tal que os que dela participam são virtuosos, sejam os agentes bons, sejam as próprias ações ou operações. Suas consequências ou frutos são o regozijo, a alegria e outros semelhantes". (1949. p.66)

Entendendo o que é a virtude podemos sem dificuldades entender o que é o vício, que para o estoicismo se baseia na ignorância: uma vez que a razão nos permite compreender as coisas e o ato de compreendêlas desemboca na virtude, o vício, ao contrário, é o resultado da má compreensão ${ }^{9}$, que nos leva à falsidade e nos impede de agir de acordo com a ordem natural; o que, conseqüentemente, resulta em tristezas. “As consequências ou frutos dos vícios são a tristeza, a aflição e outros semelhantes". (LAERCIO 3. p.66)

O virtuoso é, portanto, aquele que segue a razão e está sempre em adequação com a natureza, enquanto o vicioso é o que está na ignorância e na falsidade, e por isso é vulnerável às paixões.

As paixões parecem ser o ponto central da ética estoica, são elas que causam os malogros humanos e para modificá-las os estoicos estudaram sua natureza e funcionamento. Diziam eles que as paixões são perversões na mente geradas por coisas falsas, movimentos irracionais da alma, que por serem irracionais são contra a natureza ${ }^{10}$, como dissemos acima. No entanto a análise parece ir mais além, pois assim como a virtude existe no homem por meio de sua condição racional, o vício também é uma particularidade humana e deve sua existência às opiniões (doxái)ou seja, falsos juízos - que nascem da crença em uma falsidade. Tad Brennan corrobora nossa afirmação quando diz que "o que distingue os sentimentos de outros impulsos é que eles incluem uma caracterização de seus objetos como bons ou maus e são constituídos por crenças aquém do conhecimento.”(BRENNAN 2. p. 298)

Exemplos que corroboram essa definição não faltam quando lemos a descrição das paixões fundamentais feita pelo estoicismo: ${ }^{11}$

Desejo é a opinião de que alguma coisa futura é um bem, de modo que devemos alcançá-la.

Medo é a opinião de que alguma coisa futura é um mal, de modo que devemos evitá-la.

Prazer é a opinião de que alguma coisa presente é um bem, de modo que devemos exultar perante ela.

Dor é a opinião de que alguma coisa presente é um mal, de modo que devemos abater-nos perante ela. (BRENNAN 2. p. 299)

No entanto, para entendermos com clareza porque os estóicos caracterizavam as paixões como sendo resultado de um juízo de valor sobre algo, temos que expor a existência do que eles nomeavam "indiferentes".

Os indiferentes são um gênero de coisas que não são boas nem más, e que não influenciam na felicidade ou tristeza dos homens. ${ }^{12} \mathrm{O}$ problema é que os indiferentes somam grande parte das coisas que existem; uma vez que somente a virtude é um bem, e somente o vício é um mal, todo o resto - como saúde, doença, riqueza, miséria, fama, glória, infâmia, etc. - não deve ser valorado. A valoração de um indiferente é própria dos homens cujo entendimento da ordem natural é deficiente e que, por isso, não são capazes de compreender que algo que pode ser usado tanto para o bem quanto para o mal não pode ser nem uma coisa, nem outra: “As riquezas e 
a saúde não são mais proveitosas que danosas; logo, nem as riquezas nem a saúde são bens. Mais ainda: aquilo que se pode utilizar bem ou mal, não é bom". (LAERCIO 3. p.71)

Depois de descrevermos o funcionamento da virtude e do vício, passaremos sem mais delongas à explicação do que vem a ser o Sábio símbolo de virtude e felicidade tão perseguido pelos estoicos e, no entanto, tão difícil de ser alcançado.

O Sábio é aquele que adquiriu imunidade ao erro; ele não tem opiniões e muito menos o que delas decorre: as paixões, uma vez que estas são provenientes de um juízo falso sobre a verdadeira natureza de algo. O Sábio conhece e vive de acordo com a ordem natural, deixando-se guiar pela razão e fugindo, dessa forma, do erro. ${ }^{13}$ Será então, uma vez que o Sábio não possui paixões, permitido dizer que ele é um sujeito apático, duro e sem movimentos na alma? Mais uma vez, Laércio nos esclarece essa dúvida com muita precisão:

"Dizem que há três afecções boas do espírito: o regozijo, a precaução e a vontade. Que o regozijo é contrário ao deleite, pois é um movimento racional. Que a precaução o é ao medo, sendo uma rejeição racional ao perigo. Assim, o sábio nunca teme, mas se precavém. E que a vontade é contrária à concupiscência, já que aquela é um desejo racional. (...) Dizem que o sábio permanece sem paixões, por acharse livre de quedas. Que também há outro sem paixões, a saber o mau ou ignorante, que é como dizer duro e imóvel." (LAERCIO 3. p.81)

Como podemos ver, o Sábio está livre de paixões, mas possui uma espécie de boa afecção chamada por eles de eupátheiai. Essas boas afecções são a alegria (khará), a vontade (boúlesis) e a cautela (eulábeia); sua principal característica em comum é a de serem movimentos racionais da alma, ao contrário das paixões, nas quais o movimento é sempre irracional.

Dessa forma entendemos que a principal diferença entre o Sábio e o ignorante é o uso da razão, pois já vimos que o que gera perturbações na alma é apenas a opinião - que consiste justamente em cair na falsidade. O falso, portanto, não está nas coisas em si mesmas, e sim no juízo que fazemos sobre elas, como nos demonstra Cícero na seguinte passagem:

"Além disso, as afecções da mente, que acossam e amarguram a vida dos tolos (...) não se excitam por influência da natureza; são todas elas meras fantasias e opiniões frívolas. O homem sábio, portanto, estará sempre livre delas”. (CICERO 5. p.255)

O Sábio não é, então, um sujeito vazio e apático - isso se encaixaria mais com a descrição do ignorante ${ }^{14}$ - ele é alguém com conhecimento sobre a ordem da natureza, que entende que a maldade e a bondade só se encontram no vício e na virtude (e não nas demais coisas do mundo, que são indiferentes) e guia sua vida de acordo com o princípio natural da conservação de si, e para isso se vale da razão, que é sua ferramenta natural para alcançar a vida feliz.

Deduzimos com isso que o Sábio não busca a simples e total erradicação de movimentos na alma, como pode parecer numa leitura mais ingênua, e sim a modificação dos movimentos irracionais (contrários à natureza) em movimentos racionais, que o levem à virtude, à felicidade e à liberdade. ${ }^{15}$

\section{O estoicismo romano: a semente da ética ocidental}

O estoicismo teve grande força na filosofia romana, principalmente no período entre o final da República e os dois primeiros séculos do Império, e apesar de dar continuidade às suas três áreas de investigação, 
a ética e a política foram os campos mais explorados e desenvolvidos. Tomando como base os fundamentos dos primeiros estoicos, ${ }^{16}$ os romanos constituíram novas formas de fazer filosofia e discutir o estoicismo.

Panécio, o filósofo de Rodes, foi uma das principais influências do estoicismo romano. Frequentador do círculo dos Cipiões, o filósofo tanto influenciou a alta sociedade romana como, em contrapartida, teve sua filosofia influenciada pela opulência daquela pátria que crescia e prosperava. Vendo e vivendo num estado de coisas bem diverso daquele que os seus antecessores estoicos estavam acostumados, Panécio introduziu algumas mudanças no estoicismo clássico - e foi a partir de então que a escola do Pórtico aos poucos foi perdendo o rigor dos primeiros tempos e se tornando cada vez mais adequada ao perfil romano. ${ }^{17}$

O filósofo de Rodes revisou teses que já haviam sido duramente atacadas pelas escolas cética e epicurista, e colheu, ao seu modo, novas ideias derivadas dos ensinamentos de Platão e Aristóteles. Modificou o foco das ações para os deveres, reinterpretou o conceito de apatia e desenvolveu os conceitos de virtudes práticas, como a justiça, a magnanimidade, e a temperança. ${ }^{18}$ Esta reformulação do estoicismo permitiu que a parte de interesse mais prático da filosofia - como ética, moral e política - se sobressaíssem, agregando ainda mais valor à doutrina como um todo perante os romanos.

Cícero, que era um dos principais nomes da política e da intelectualidade romana ao final da República, escreveu o De Officiis (Do dever), livro homônimo ao que tinha escrito Panécio algumas décadas antes e no qual, ao que tudo indica, o pensador romano realiza uma emulação do livro do estoico de Rodes, valendo-se das novas ideias trazidas por Panécio em relação à virtude, Cícero tornou os ensinamentos estoicos ainda mais afeitos aos interesses de seu Estado:
"Panécio não tematizou a superioridade da virtude prática sobre a teórica, como fará Cícero, aproveitando-se do enfoque paneciano. Todavia, ele valorizou a vida prática, trouxe ao Pórtico um vivo sentido da socialidade e um forte sentido do Estado, que absorveu dos romanos e, assim, de algum modo, enfraquecendo o vago cosmopolitismo dos predecessores."(Reale 10, 372)

E foi dessa forma, já um tanto diverso do estoicismo clássico e sob influência da Academia e do Liceu, que o estoicismo se introduziu na Roma que transitava da República ao Império.

O enfoque na ética prática, ${ }^{19}$ que correspondia na maior parte das vezes, a aconselhamentos destinados a pessoas que buscavam a sabedoria, era o principal uso dado à filosofia estoica entre os romanos. Esses aconselhamentos se centravam principalmente "na determinação de que tipo de ações seriam, com efeito, 'apropriadas', bem como no estabelecimento, na vida das pessoas, entre obter vantagens 'preferíveis' e agir de maneira virtuosa (ou, pelo menos, fazer progressos em direção à virtude.)" (GILL 8, p. 44)

Outro aspecto fundamental da ética estoica romana era a atenção que se destinava ao estudo das paixões, que continuaram sendo encaradas como "distúrbios de nosso estado psicofísico natural" (Id. Ibid.) e, apesar de ainda serem caracterizadas como um erro na razão, passavam agora a serem tratadas como "doenças" que precisavam ser "curadas"; essa cura se dava muitas vezes por meio de fatores externos, como o aconselhamento, e não mais individualmente, através da própria capacidade racional, como indicava o estoicismo grego.

Com o correr dos anos, a ética estoica ganhou terreno e começou a ditar o comportamento de grande parcela dos nobres romanos - que eram os que tinham acesso aos estudos filosóficos - e acabou, por fim, difundindo-se para o restante da população. 
A difusão do estoicismo, misturada à divulgação de muitas outras doutrinas no solo romano, fez com que as ideias - antes específicas de cada escola - se contaminassem mutuamente gerando pensadores ecléticos que colhiam o que lhes apetecia de cada doutrina criando fusões das mais diversas possíveis. Esse é o caso de Díon Cocciano de Prusa - também conhecido como Crisóstomo - em cujo pensamento "predomina um posicionamento cínico-estoico de gênero amplamente similar a Musônio e Epiteto, mas incorporando também algumas ideias platônicas." (GILL 8, p. 57)

O estoicismo romano a essa altura já havia perdido boa parte de sua unidade e concisão - que faziam dele uma filosofia consistente e sistemática na antigüidade - pois tinha parcialmente abandonado as outras duas áreas de conhecimento da doutrina (física e lógica), concentrando-se na ética e deixando, com isso, alguns conceitos - outrora tão firmemente embasados - sem fundamento. Assim, a ética estoica começou a apoiar-se numa nova lógica e numa nova metafísica, fazendo com que conceitos mais gerais como "virtude" e "razão" fossem reinterpretados:

A partir de Clemente de Alexandria (aproximadamente 200) o platonismo médio passou a exercer forte influência sobre a evolução da doutrina cristã, e foi em seu rastro que os pensadores cristãos absorveram idéias estóicas tais como o papel cósmico do lógos (a razão) e a suficiência da virtude, ainda que compreendida em termos platônicos médios. (GILL 8, p. 60)

Essa redefinição de conceitos foi fatal para o estoicismo, fazendo com que ele perdesse força e fosse sendo gradualmente substituído pela doutrina cristã; essa mesma doutrina que, superficialmente, conservava vestígios do estoicismo, mas que em seu fundamento construía um sistema significativamente distinto daquele defendido pela filosofia do pórtico, tanto no que diz respeito à sua metafísica, quanto no que tange à sua ética.

\section{A visão moderna e o estereótipo}

Como dissemos acima, o estoicismo foi se difundindo e perdendo força com o passar do tempo, e o que vemos durante as Idades Média e Moderna são inúmeras referências ao estoicismo como sendo uma corrente filosófica que prega o comodismo, a aniquilação dos sentimentos e o domínio absoluto da razão sobre as paixões. O que não espanta: depois de sofrer tantas alterações, dificilmente os vestígios do estoicismo espalhados pelas correntes filosóficas assemelhar-se-iam ao estoicismo em sua forma clássica, ou seja, o pensamento que nasceu na Grécia e se desenvolveu até o início da era imperial romana. O nosso objetivo neste texto é justamente determinar até que ponto a classificação da modernidade e, em certa medida, da contemporaneidade, feita sobre o estoicismo condiz com o estoicismo clássico, e até onde ela é apenas a confusão dos vestígios estoicos misturados a outras doutrinas.

Em primeiro lugar, quem acusa o estoicismo de 'filosofia do comodismo' demonstra que não compreendeu bem o papel do determinismo estoico em sua ética. Não era o objetivo de nosso trabalho abordar as questões metafísicas, mas podemos contar com o significativo texto de Frede, que dedicou um artigo só para o assunto. Nele, ela se pergunta:

até que ponto se justifica o estereótipo contemporâneo que vê o rigor moral estoico e a supressão de todos os sentimentos como consequência de uma resignação 'fatídica'? (...) os estoicos não só estavam longe de tal resignação como tinham boas razões para recomendar o envolvimento ativo com as preocupações mundanas. Se tratavam as paixões humanas como impedimento, não era por advogar a aquiescência à ordenação do destino. Eles acreditavam, antes, que as paixões interferem na nossa capacidade de lidar tão razoavelmente quanto possível com as condições 
existentes e seguir nossa concepção sobre qual é o melhor curso a tomar - mesmo que não haja garantia de êxito. $\mathrm{O}$ determinismo estoico, portanto, não conduz à resignação, mas ao estudo cuidadoso de nossas aptidões e de nossas limitações. (FREDE 7. p. 227)

Acreditamos ter esclarecido, na segunda parte de nosso texto, que os estoicos não buscavam a aniquilação dos sentimentos da alma, mas os bons sentimentos (eupátheiai) que se caracterizavam por serem impulsos racionais, e que por isso se encaixariam muito mais no ideal de ataraxia (a imperturbabilidade da alma) do que no de apatia - que ficaria melhor como título do que eles mesmo chamam "ignorância".

Por último, temos a mais comum das acusações, a saber: que os estoicos buscavam domínio absoluto sobre as paixões. Um exemplo possível dessa acusação é feita pelo pensador moderno Spinoza, que no prefácio ao quinto livro de sua Ética cita nominalmente os estoicos, afirmando que estes defendiam que as paixões dependiam inteiramente de nossa vontade e que podemos comandá-las absolutamente. ${ }^{20}$ Estaria correto, se Spinoza se referisse aos neo-estoicos de sua época ${ }^{21}$; no entanto, se seguirmos com a leitura do prefácio veremos o pensador dizer que os estoicos confessaram, não por causa de seus princípios, mas sim pelos protestos da experiência, que se requer prática e esforço para refrear as paixões. Com isso podemos perceber que ele não se refere aos neoestoicos unicamente, mas também aos estoicos antigos e provavelmente aos estoicos romanos - dos quais sabemos que foi leitor. Mas será que a afirmação de que as paixões dependem absolutamente da nossa vontade é consistente quando aplicada aos filósofos da Antigüidade? Long indicanos que não: "Spinoza parece confundir a tese estóica de que as paixões são juízos ou funções da mente racional com a liberdade da vontade em relação à causalidade antecedente" (LONG 9. p. 414). Nós já explicamos o que são os 'juízos da mente racional': são valorações das coisas do mundo que, quando falsas, geram paixões. Mas o que vem a ser 'causalidade antecedente' na doutrina estoica?

Causalidade antecedente (prokatarktiká) é o conceito estoico usado para se referir às causas externas ao próprio homem. No entanto, para entendermos o porquê de Long se referir a essa tese, temos de lançar luz sobre outra tese estoica - que trata das causas internas - e delimitar uma através da outra. E para isso mais uma vez buscaremos a ajuda de Frede:

(...) os estóicos fiavam-se em uma distinção entre a causa antecedente ou externa e a causa principal ou "interna" com o intuito de explicar como os seres humanos são parte da rede de interconexões causais de modo que haja espaço para a responsabilidade pessoal. A justificativa estóica consiste em fazer das causas internas, embora não das externas, as causas principais das ações humanas. Embora o ambiente aja sobre nós de um modo que não está em nosso poder, nossas reações "estão em nosso poder", visto que dependem de nosso estado interior. Clemente explica essa interação como segue. A visão da beleza provoca amor em um homem desgovernado (akólastos). A visão da beleza é a causa antecedente. A reação da pessoa está, no entanto, "em seu poder", visto que sua atitude amorosa com a beleza física é, afinal de contas, parte de sua constituição interna, e não é causada pela impressão externa. (FREDE. 2006, p. 212)

O que Frede nos diz é que as nossas reações (que sabemos implicitamente serem paixões ou eupathéiai) estão sim em nosso poder, só que indiretamente. Nós temos controle sobre a nossa constituição interna, mas não sobre o efeito que será gerado a partir do contato desta com a causa externa, ou seja, as reações; dessa forma o que nós podemos modificar é somente a causa interna e a partir dela - indiretamente - controlar as reações, uma vez que essas são provenientes da causa principal que nada 
mais é que a causa interna. Mas essa modificação na constituição interna se dá por meio da razão? Mais uma vez a resposta é positiva e mais uma vez o processo se dá indiretamente.

Como acima nos disse Long, o que se liga à tese das causas antecedentes e o que Espinosa parece ter considerado ao criticar os estoicos é a "liberdade da vontade", e como vimos na segunda parte deste texto, a 'vontade' é, no estoicismo, um eupátheia (um bom afeto, ou uma boa paixão). Com isso temos então que o responsável por modificar a causa interna é um afeto; proveniente da razão, mas ainda assim um afeto.

Dessa forma podemos dizer que, sim, os estoicos defendem que temos algum poder sobre as paixões através da razão, mas de forma alguma esse poder é "absoluto", como afirma Espinosa. A razão está a pelo menos dois graus de distância na rede causal de controle das paixões, e seria muito mais seguro acusar os estoicos de quererem controlar um afeto irracional (paixão) através de um afeto racional (eupátheia) do que de tentar controlar as paixões por meio da razão, como se esta fosse um tirano, e não um instrumento na missão de adequação à natureza.

Por fim, temos mais um agravante nas sutilezas da teoria estoica no que diz respeito ao controle das paixões pela razão. Sêneca, no De ira, nos atesta a dificuldade de delimitar fronteiras entre razão e paixão na teoria estóica: "a paixão e a razão não ocupam lugares particulares e separados, são apenas modificações do espírito, para o bem e para o mal" (SÊNECA, 1977, livro III-8)

Como afirmamos no início do texto, essa nossa exposição teve como objetivo mapear a ética estoica fornecendo ferramentas para melhorar nossa compreensão e nos prevenir contra os estereótipos constantemente associados ao Estoicismo, e que mais informam sobre as correntes que se apossaram de alguns conceitos estoicos, do que sobre a filosofia estóica em sua forma original.
Não podemos negar o legado que a Stoá nos deixou e, por isso, é fundamental que compreendamos esta doutrina. Suas marcas se refletem em nós não só através de conceitos ético-filosóficos eternizados por pensadores de todos os períodos históricos, como também em nossas posturas religiosas, ainda que na maior parte das vezes contaminadas por outras correntes de pensamento. Entretanto, nós, brasileiros, temos na poesia um grande representante que, de forma suave, fiel e magnífica representa toda a aridez dos conceitos estoicos aos quais nos referimos ao longo do texto. Mais uma prova de que o estoicismo está mais presente em nossa cultura do que podemos imaginar:

\section{Ser como o rio que deflui}

silencioso dentro da noite.

Não temer as trevas da noite.

Se há estrelas no céu, refleti-las.

E se os céus se pejam de nuvens, como o rio as nuvens são água, refleti-las também sem mágoa, nas profundidades tranqüilas.

(O Rio, de Manuel Bandeira, 1)

\section{THE ANCIENT STOIC ETHICS AND THE STOIC STEREOTYPE IN THE MODERNITY}

Abstract: Considering that Stoicism is the most influent Hellenistic stream on Western philosophy, our intention is to present some of the most common stereotypes created by modern philosophy to convey Stoic ethical theory. With this in view, we make a presentation of the most famous aspects of Stoic ethics and analyze the concepts which later will be object of criticism to the school of Stoa. Charged with being a philosophical stream that defends self-indulgence, feeling- annihilation and the absolute domination of reason over passions, stoicism is often misinterpreted by its opponents. We also point here Spinoza's criticism on fifth Ethics book's preface, where the emphasis on concepts such as "experience" and "will" helps to clarify the way in which stoicism is seen in modern philosophy. 
Keywords: Ethics, Stoics ethics, Roman stoicism, Stoicism in modern philosophy, Stoics and Spinoza.

\section{REFERÊNCIAS BIBLIOGRÁFICAS:}

1.BANDEIRA, Manuel. Estrela da Vida Inteira. Poesias Reunidas. $11^{\text {a }}$ ed. Rio de Janeiro: José Olympio, 1986.

2.BRENNAN, Tad. Psicologia moral estóica. In: INWOOD, Brad (org). Os Estóicos. São Paulo: Odysseus Editora, 2006.

3.LAERCIO, Diogenes. Vidas de los filosofos mas ilustres. Madrid : Espasa-Calpe, 1949.

4.CICERO, Marco Tulio. Cuestiones Académicas. Mexico : Colegio de Mexico, 1944.

5.CICERO, Marcus Tulius. De finibus bonorum et malorum. Cambrigde: Harvard University Press, 1999.

6.INWOOD, Brad (org). Os Estóicos. São Paulo: Odysseus Editora, 2006.

7.FREDE, Dorothea. Determinismo estóico. In: INWOOD, Brad (org). Os Estóicos. São Paulo: Odysseus Editora, 2006.

8.GILL, Christopher. A escola no periodo imperial romano. In: INWOOD, Brad (org). Os Estóicos. São Paulo: Odysseus Editora, 2006.

9.LONG, A.A. Estoicismo na tradição filosófica: Spinoza, Lipsius, Bluter. In: INWOOD, Brad (org). Os Estóicos. São Paulo: Odysseus Editora, 2006.

10.REALE, Giovanni. História da filosofia antiga / Giovanni Reale - São Paulo: Loyola, 1994.

11.SEDLEY, David. A escola, de Zenon a Ário Didimo. In: INWOOD, Brad (org). Os Estóicos. São Paulo: Odysseus Editora, 2006.

12.SCHOFIELD, Malcolm. Ética estóica. In: INWOOD, Brad (org). Os Estóicos. São Paulo: Odysseus Editora, 2006.

13.SPINOZA, Benedictus de. Ética / Spinoza ; [tradução de Tomás Tadeu]. - Belo Horizonte: Autêntica Editora, 2009

\section{NOTAS:}

1. Long, (9, p. 430) no texto "A complexidade do legado estóico", traça uma breve linha histórica de influências do Estoicismo, que vai desde o período romano, com Cícero e Marco Aurélio, até a modernidade, apontando as influências estoicas na Filosofia prática de Kant, por exemplo.
2. "Dizem, pois, os estoicos que a filosofia se divide em três partes, a saber: em natural, moral e racional ou lógica..” (LAERCIO 3, p. 30)

3. Podemos testemunhar o caso de Sêneca, que nada falava sobre lógica e muito tratava sobre ética, diferentemente de Crisipo, que parece ter dado atenção igualitária a todas as áreas. Seus trabalhos sobre lógica foram fundamentais para o desenvolvimento do pensamento estóico, como afirma David Sedley 11, p.18.

4. "a arte de viver é mais semelhante à da luta que à da dança, na medida em que se posiciona, preparada e imóvel, contra o que golpeia e o que é inesperado"

5. Demos preferência, sempre que possível, às citações em português.

6. "A primeira inclinação de todo animal é sua constituição e seu conhecimento próprio, pois não é verossímil que o animal alienasse esta sua inclinação ou que fizesse de modo que nem a alienasse nem a conservasse" (LAERCIO 3, p.60)

7. "Aos [animais] racionais foi dada a razão como principado mais perfeito, a fim de que vivendo de acordo com ela sejam retamente conforme a natureza." (LAERCIO 3, p.61) 8. "Obedecendo às injuções da razão reta, obedecemos à razão divina que preside sobre a administração da realidade. Se obedecermos a elas de modo consistente, alcançaremos a virtude e o "suave fluir da vida", visto que todas as nossas ações serão então conformes à harmonia entre o divino em nós e a vontade do administrador do todo." (SCHOFIELD 12, p. 273)

9. "O vício é a ignorância de tudo quanto seja virtude saber" (LAERCIO 3, p.66)

10. "Das coisas falsas provém perversão na mente, e dela brotam muitas paixões ou perturbações e motivos de inconstância. Segundo Zenão, a perturbação ou paixão é um movimento, na alma, irracional e contra a natureza." (LAERCIO 3, p. 75)

11. Grifo nosso.

12. "Só a virtude, juntamente com o que quer que nela participe, é um bem; só o vício, e o que quer que nele participe, é um mal. Tudo o mais é indiferente, o que significa que não é nem benéfico nem nocivo, ou, de modo equivalente, não exerce efeito sobre a felicidade ou a tristeza do indivíduo." (BRENNAN 2, p. 292)

13. "O erro e a temeridade, a ignorância e a opinião, a conjetura e, numa palavra, tudo o que fosse alheio ao assentimento firme e constante, [Zenão] removia da virtude e sabedoria." (CICERO 4, p. 17)

14. Como vimos acima na citação de Diógenes Laércio.

15. "Só o sábio é livre, os maus e os ignorantes são escravos" (LAERCIO 3,. p.82) 16. “(...) o ensinamento estóicos se baseava em um canôn bem estabelecido de tratados e escritos. Embora Zenon continuasse a desfrutar de um estatuto especial como 
fundador da escola, o corpo substancial de trabalhos oriundos da pena de Crisipo - o grande pensador sistemático do estoicismo - constituía a essência do corpus estóico nesse período." (GILL 8, p 39)

17. “(...), fundamental, sobretudo na revisão da moral estóica, foi o contato de Panécio com a mentalidade romana. Acolhido em Roma no círculo dos Cipiões, frequentando assiduamente os romanos mais poderosos, influentes e esclarecidos do momento, ele compreendeu a grandeza e a novidade da romanidade, foi fascinado e em certa medida, também, positivamente condicionado por ela. Os seus predecessores viram na Grécia, prioritariamente, o que no âmbito do Estado e da política estava se destruindo e se perdendo; Panécio, viu em Romana, ao contrário, o que nesse âmbito se estava construindo e se afirmava sempre mais. E assim ele recuperou o forte sentido político, que já fora o traço distintivo dos gregos da era clássica, embebeu-se do forte sentido prático que constituía a cifra característica da romanidade. Um e outro elemento incidiram fortemente sobre a visão da vida do filósofo." (REALE 10, 366)

18. "Também na determinação das virtudes, Panécio afastou-se em parte do antigo Pórtico. Ele parece retomar a distinção entre virtude teórica e virtude prática.(...) Virtude teórica é o saber, virtudes prática são: a justiça, a magnanimidade, e a temperança. Essas virtudes exertam-se sobre quatro tendências fundamentais do homem: o desejo de puro saber, o desejo de conservar a si e à comunidade, o desejo de não depender de ninguém e de nada, o desejo de moderação. As virtudes são, precisamente, a atuação e a explicitação desses desejos em conformidade com a razão. (Reale 10, 371 -372)

19. Como atesta Gill: "uma área em que a filosofia estóica é claramente criativa nesse período é a área de ética prática ou aplicada”.(8, p. 43)

20. “(...) Que não temos, com efeito, um domínio absoluto sobre os afetos foi o que demonstramos anteriormente. Os estóicos, entretanto, acreditavam que os afetos dependem exclusivamente de nossa vontade e que podemos dominá-los inteiramente. Contudo, viram-se obrigados, na verdade, não por causa de seus princípios, mas diante das evidências da experiência, a admitir que não são pequenos o exercício e o esforço necessários para refrear e regular os afetos, conclusão que um deles tentou demonstrar (se bem me recordo) pelo exemplo de dois cães: um, doméstico; de caça, o outro. O resultado foi que, pelo exercício, ele acabou conseguindo que o cão doméstico se acostumasse a caçar e que o de caça, em troca, deixasse de perseguir as lebres." (SPINOZA 13, p. 213 - Pref. Et. V)

21. Long nos indica que Lipsius procedia da mesma maneira. (LONG 9, p. 414)

\section{O CONATUS EM ESPINOSA E A TODESTRIEB \\ DE FREUD: UMA ANTINOMIA ONTOLÓGICA OU PURAMENTE IMAGINATIVA?}

Lucas Carpinelli*

Resumo: Das muitas aproximações perpetradas nas últimas nove décadas entre Sigmund Freud e Espinosa, talvez nenhuma seja tão problemática quanto o cotejamento entre o conatus - esforço de perseveração no ser que, na Ética de Espinosa, constitui a essência atual das coisas - e aquela força autodestrutiva a que Freud, em Além do Princípio do Prazer, dá o nome de Todestrieb, ou pulsão de morte. De que forma, à luz de uma ontologia absolutamente positiva como a de Espinosa - uma na qual a destruição de uma coisa será sempre extrínseca à mesma -, devemos receber a asserção de Freud de que há algo na constituição do sujeito que o destrói? Partindo desta questão, o intento do presente trabalho é realizar uma apresentação detida dos conceitos, a fim de determinar em que registro se dá a contradição, e até que ponto a mesma nos constrange a suprimir nossa aquiescência a um ou outro dos mesmos.

Palavras-chave: Espinosa, Freud, conatus, pulsão, morte.

Nenhuma coisa pode ser destruída senão por uma causa exterior. (...) Cada coisa esforça-se, tanto quanto está em si, por perseverar em seu ser

Espinosa $^{1}$

Se tomarmos como verdade que não conhece exceção o fato de tudo o que vive morrer por razões internas, (...) seremos então compelidos a dizer que o objetivo de toda vida é a morte...

Sigmund Freud ${ }^{2}$

Desde a consolidação da psicanálise nas primeiras décadas do século XX, comparações e aproximações vêm sendo feitas entre as teorias

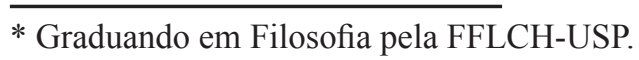

